\author{
ГУ «Днепропетровская медицинская академия МЗ Украины», г. Днепр
}

Modern Pediatrics. Ukraine. 6(110): 62-69. doi 10.15574/SP.2020.110.62

For citation: Vysochyna IL, Kramarchuk VV. (2020). Evidence base for the efficacy and safety of flavonoids and the opinion of outpatient doctors in the focus of choice of approaches to treatment of ARI. Modern Pediatrics. Ukraine. 6(110): 62-69. doi 10.15574/SP.2020.110.62

Многочисленные публикации, метаанализы и систематические обзоры предлагают различные подходы к лечению и просилактике острых респираторных вирусных инфекций (ОРВИ), поэтому в практике врача, как в Украине, так и в других государствах, существует много разнообразных схем, протоколов, нормативных документов и профессиональных рекомендаций по ведению этих пациентов. Для грамотного, эффективного и безопасного лечения и профилактики ОРВИ врач должен найти среди национальных и мировых стандартов наиболее оптимальный и действенный алгоритм ведения пациентов с вирусными инфекциями респираторного тракта. Данный алгоритм в идеале должен иметь высокий уровень доказательной медицины и может быть использован в конкретной практике с точки зрения ведения и маршрутизации пациента.

Цель - проанализировать уровень осведомленности врачей общей практики - семейной медицины в вопросах о существующей в Украине и мире нормативной базе и национальных протоколах ведения пациентов с ОРВИ; изучить мнение семейных врачей об эффективности и безопасности применения флавоноидов в лечении и профилактике ОРВИ.

Материалы и методы. Проведено анонимное анкетирование 149 семейных врачей г. Днепр и области в 2020 г. Среди респондентов было 55 (37\%) врачей с первичной специализацией «Педиатрия», 37 (25\%) врачей с первичной специализацией «Внутренняя медицина» и 57 (38\%) врачей с первичной специализацией «Семейный врач». Проверка нормальности распределения проведена с использованием критерия Колмогорова-Смирнова. С учетом того, что 90\% данных имели нормальное распределение, использованы методы параметрической статистики. Для оценки связей между бинарными признаками использован ф-коэффициент взаимной сопряженности. Критический уровень статистической значимости принят $<5 \%(p<0,05)$

Результаты. Семейные врачи осведомлены в вопросах о современных тенденциях стратегии терапии и просилактики ОРВИ. По мнению семейных врачей, препараты с действующем веществом протефлазид для лечения и профилактики ОРВИ безопасные (отсутствует токсическое действие) и эффективные (по собственным наблюдениям), за счет уменьшения продолжительности и тяжести заболевания, выраженности лихорадки и проявлений интоксикационного синдрома, снижения частоты ОРВИ (кратность за год). Вышеполученные эффекты в практике опрошенных семейных врачей связаны с прямым противовирусным действием, подавлением размножения вирусов и множественными механизмами действия биофлавоноидов протефлазида. Помимо профессионального мнения семейных врачей, достаточно важным является мнение родителей об эффективности препаратов С действующим веществом протефлазид для лечения и профилактики ОРВИ (обратная связь с врачом). Получены положительные отзывы и сделаны отметки о том, что родители часто используют эти препараты при самолечении, а такой выбор связан с тем, что препараты линейки протефлазида сокращают период болезни и, по отзывам родителей, дети меньше болеют ОРВИ.

Выводы. Доказанное в современной мировой практике противовирусное действие фллавоноидов как класса полифенольных соединений, а также доказанный механизм противовирусной активности фрлавоноидов, входящих в состав препарата Флавовир, что в клинической амбулаторной практике подтверждено положительным опытом врачей первичного звена (выраженная клиническая эффективность), позволяет рекомендовать Флавовир сироп для лечения и профилактики гриппа и сезонных ОРВИ детям от рождения.

Исследование выполнено в соответствии с принципами Хельсинской Декларации. Протокол исследования утвержден Локальным этическим комитетом указанного в работе учреждения. На проведение исследований получено информированное согласие врачей.

Авторы заявляют об отсутствии конфликта интересов.

Ключевые слова: ОРВИ, фрлавоноиды, лечение, амбулаторная практика, доказательная медицина.

\title{
Evidence base for the efficacy and safety of flavonoids and the opinion of outpatient doctors in the focus of choice of approaches to treatment of ARI \\ I.L. Vysochyna, V.V. Kramarchuk
}

SI «Dnipropetrovsk medical academy of the Ministry of Health of Ukraine», Dnipro

Numerous publications, meta-analyzes and systematic reviews suggest different approaches to the treatment and prevention of ARI, therefore, in the practice of a doctor both in Ukraine and in other countries, there is a variety of schemes, protocols, regulations and professional recommendations for the management of these patients. Therefore, for competent, effective and safe treatment and prevention of ARI among national and world standards, a doctor needs to find the most optimal and effective algorithm for the management and treatment of viral infections of the respiratory tract, which ideally has a high level of evidence-based medicine and can be used in specific practice with the point of view of patient management and routing.

Purpose - to analyze the knowledge of the existing in Ukraine and the world of the regulatory framework and national protocols for the management of patients with ARI by general practitioners - family medicine, as well as to study the opinion of family doctors about the efficacy and safety of using flavonoids in the treatment and prevention of ARI.

Materials and methods. Anonymous survey of 149 family doctors in the city of Dnipro and the region was conducted in the current 2020. Among the respondents there were 55 doctors with a primary specialization in Pediatrics (37\%), 37 doctors with a primary specialization in Internal Medicine $(25 \%)$ and 57 with a primary specialization in Family Medicine $(38 \%)$. The distribution normality was checked using the Kolmogorov-Smirnov test. Considering that $90 \%$ of the data were normally distributed, we used parametric statistics methods. To assess relationships between binary features, the $\varphi$-coefficient of mutual conjugation was used. The critical level of statistical significance was accepted as $<5 \%(p<0.05)$.

Results. Family physicians are aware of current trends in the strategy of therapy and prevention of ARI. According to family doctors, drugs with the active substance Proteflazid, when prescribed for the treatment and prevention of acute respiratory viral infections, are safe (no toxic effect) and effective (according to our own observations) by reducing the duration and severity of the disease, the severity of fever and manifestations of intoxication syndrome, reducing the frequency of acute respiratory diseases (frequency rate per year), and that the above effects obtained in their own practice are associated with direct antiviral action, suppression of viral reproduction and multiple mechanisms of action of Proteflazid bioflavonoids. In addition to the professional opinion of family doctors, the opinion of parents about the effectiveness of drugs with the active substance Proteflazid for the treatment and prevention of ARI (feedback from a doctor) in the form of their positive feedback and a note that they are often used for self-treatment, and their choice is associated with the fact that Proteflazid preparations shorten the period of illness and, according to parents, children are less ill with ARI.

Conclusions. The presence of the proven antiviral action of flavonoids, as a class of polyphenolic compounds, and the fact that the flavonoids that make up Flavovir have a proven mechanism of antiviral activity, which is confirmed in clinical outpatient practice by the positive experience of primary care physicians (pronounced clinical efficacy) allows you to recommend Flavovir syrup for the treatment and prevention of influenza and seasonal ARI to children from birth. 
The research was carried out in accordance with the principles of the Helsinki Declaration. The study protocol was approved by the Local Ethics Committee of these Institutes. The informed consent of the doctors was obtained for conducting the studies.

No conflict of interest was declared by the authors.

Key words: ARI, flavonoids, treatment, outpatient practice, evidence-based medicine.

\section{Доказова база ефективності та безпеки флавоноїдів і думка лікарів амбулаторної практики у фокусі вибору підходів лікування ГРВІ \\ І.Л. Височина, В.В. Крамарчук}

ДЗ «Дніпропетровська медична академія М03 України», м. Дніпро

Чисельні публікації, метааналізи та систематичні огляди пропонують різні підходи до лікування і профілактики гострих респіраторних вірусних інфекцій (ГРВІ), тому на сьогодні в практиці лікаря, як в Україні, так і в інших державах, існує багато різноманітних схем, протоколів, нормативних документів та професійних рекомендацій щодо ведення пацієнтів із ГРВІ. Для грамотного, ефективного та безпечного лікування і профілактики ГРВІ лікар має обрати серед національних і світових стандартів найбільш оптимальний та дієвий алгоритм ведення пацієнтів 3 вірусними інфекціями респіраторного тракту. Такий алгоритм в ідеалі повинен мати високий рівень доказової медицини і може бути використаний у конкретній медичній практиці з точки зору ведення і маршрутизації пацієнта.

Мета - проаналізувати рівень обізнаності лікарів загальної практики - сімейної медицини щодо нормативної бази та національних протоколів ведення пацієнтів із ГРВІ в Україні та світі; вивчити думку сімейних лікарів про ефективність і безпечність застосування фллавоноїдів у лікуванні і профілактиці ГРВІ.

Матеріали та методи. Проведено анонімне анкетування 149 сімейних лікарів м. Дніпро і області в 2020 р. Серед респондентів було 55 (37\%) лікарів із первинною спеціалізацією «Педіатрія», 37 (25\%) лікарів із первинною спеціалізацією «Внутрішня медицина» і 57 (38\%) лікарів із первинною спеціалізацією «Сімейний лікар». Перевірка нормальності розподілу проведена з використанням критерію Колмогорова-Смірнова. 3 урахуванням того, що 90\% даних мали нормальний розподіл, застосовано методи параметричної статистики. Для оцінки зв'язків між бінарними ознаками використано $\varphi$-коефріцієнт взаємної спряженості. Критичний рівень статистичної значущості прийнято $<5 \%(p<0,05)$.

Результати. Сімейні лікарі обізнані в питаннях про сучасні тенденції стратегії лікування і профрілактики ГРВІ. На думку сімейних лікарів, препарати з діючою речовиною протефрлазід для лікування і профрілактики ГРВІ безпечні (відсутня токсична дія) та ефективні (за власними спостереженнями), за рахунок зменшення тривалості і тяжкості захворювання, вираження лихоманки і проявів інтоксикаційного синдрому, зниження частоти ГРВІ (кратність за рік). Вищезазначені ефекти у практиці опитаних сімейних лікарів пов'язані з прямою противірусною дією, пригніченням розмноження вірусів і множинними механізмами дії біофлавоноїдів протефлазіду. Крім професійної думки сімейних лікарів, досить важливою є думка батьків про ефективність препаратів із діючою речовиною протефлазід для лікування і профілактики ГРВІ (зворотний зв'язок із лікарем). Отримано позитивні відгуки і позначки про те, що батьки часто використовують ці препарати при самолікуванні, а вибір пов'язаний 3 тим, що препарати протефлазіду скорочують період хвороби і, за відгуками батьків, діти менше хворіють на ГРВІ.

Висновки. Доведена в сучасній світовій практиці противірусна дія фллавоноїдів як класу поліфенольних сполук, а також доведений механізм противірусної активності флавоноїдів, які входять до складу препарату Флавовір, що в клінічній амбулаторній практиці підтверджено позитивним досвідом лікарів первинної ланки (виражена клінічна ефективність), дає змогу рекомендувати Флавовір сироп для лікування і профілактики грипу та сезонних ГРВІ дітям від народження.

Дослідження виконано відповідно до принципів Гельсінської Декларації. Протокол дослідження ухвалено Локальним етичним комітетом зазначеної в роботі установи. На проведення досліджень отримано інформовану згоду лікарів.

Автори заявляють про відсутність конфрлікту інтересів.

Ключові слова: ГРВІ, фрлавоноїди, лікування, амбулаторна практика, доказова медицина

\section{Введение}

И стория изучения проблемы острых респираторных вирусных инфекций (ОРВИ) у человека в контексте их лечения и профилактики насчитывает не одно столетие. По данным многочисленных публикаций, метаанализов, систематических обзоров, экспериментальных данных, а также по результатам исследования молекулярных механизмов развития вирусного процесса у человека на генетическом уровне, профессиональные сообщества врачей и ученых так и не разработали единого сценария лечения и профилактики ОРВИ. Вследствие вышесказанного в практике врача, как в Украине, так и в других государствах, существует много разнообразных схем, протоколов, нормативных документов и профессиональных рекомендаций по ведению этих пациентов. С другой стороны, на фармацевтическом рынке сегодня представлены тысячи наименований препаратов, рекомендованных для профилактики и лечения ОРВИ.

В связи с этим для грамотного, эффективного и безопасного лечения и профилактики
ОРВИ врач должен найти среди национальных и мировых стандартов наиболее оптимальный и действенный алгоритм ведения пациентов с вирусными инфекциями респираторного тракта. Причем данный алгоритм в идеале должен иметь высокий уровень доказательной медицины и может быть использован в конкретной практике с точки зрения ведения и маршрутизации пациента [3].

В 2014 г. среди нормативных документов Министерства здравоохранения (МЗ) Украины, регламентирующих работу первичного уровня оказания медицинской помощи, семейные врачи впервые ознакомились с адаптированным клиническим руководством, основанным на лучших европейских практиках и доказательной медицине, - «Грипп и острые респираторные инфекции». На основании этого были предложены два протокола - Унифицированный клинический протокол первичной, вторичной (специализированной) медицинской помощи взрослым и детям «Грипп» и Унифицированный клинический протокол первичной медицинской помощи взрослым 
и детям «Острые респираторные инфекции» (приказ МЗ Украины от 16.07.2014 № 499, в регламент действия которого приказом МЗ Украины от 11.02.2016 № 85 были внесены изменения и дополнения).

28 апреля 2017 года вступил в силу приказ М3 Украины от 29.12.2016 № 1422, позволяющий врачам использовать в своей работе международные клинические протоколы. В частности, в практику Украины рекомендованы протоколы медико-научного общества «Duodecim Medical Publications Ltd», которое специализируется на комплексных решениях в сфере доказательной медицины. Врачам различных специальностей предложены 962 протокола, в перечне которых нет аналога привычного для украинской практики протокола по ОРВИ, протоколы ведения пациентов с тонзиллитом и фарингитом (протокол 00007), заложенностью носа (протокол 00860), отдышкой (протокол 00113), а также протоколы 00015 «Грипп», протокол 01029 «Острые заболевания младенцев», протокол 00594 «Лихорадка у ребенка», протокол 00006 «Инфекции дыхательных путей у взрослых» и некоторые другие, разработанные в сценарии постановки диагноза по наличию симптомов у пациентов.

В свободном доступе можно ознакомиться с рекомендациями ВООЗ и ЮНИСЕФ, европейскими рекомендациями, рекомендациями профильных ассоциаций США, Великой Британии, Германии и других практик мира по ведению пациентов с ОРВИ и гриппом. При оценке информационного контента, основанного на принципах доказательной медицины, по запросу «ОРВИ, клинические рекомендации» только поисковая система «PubMed» предлагает 980 результатов для ознакомления, а библиотека Международного Кокрановского сотрудничества по запросу «acute respiratory viral infections clinical guidelines» предлагает для анализа 6664 ответа, что, с одной стороны, свидетельствует об актуальности заявленной проблемы, a c другой, - усложняет поиск ответов на поставленный вопрос.

Цель исследования - проанализировать уровень осведомленности врачей общей практики - семейной медицины в вопросах о существующей в Украине и мире нормативной базе и национальных протоколах ведения пациентов с ОРВИ; изучить мнение семейных врачей об эффективности и безопасности применения флавоноидов в лечении и профилактике ОРВИ.

\section{Материалы и методы исследования}

В соответствии с поставленной задачей проведено анонимное анкетирование 149 семейных врачей г. Днепр и области в 2020 г. Анализ выборки врачей, которые добровольно принимали участие в анонимном анкетировании, показал, что стаж работы в профессии врача составил в среднем 26,5 (SD=12,4) года. Среди респондентов было 55 (37\%) врачей с первичной специализацией «Педиатрия», 37 (25\%) врачей c первичной специализацией «Внутренняя медицина» и 57 (38\%) врачей с первичной специализацией «Семейный врач».

Статистическая обработка и анализ данных выполнены с помощью программы Statistica v.6.1 ${ }^{\circledR} \quad$ (StatSoft, CШA, серийный номер AGAR909E415822FA). Проверка нормальности распределения проведена с использованием критерия Колмогорова-Смирнова. С учетом того, что 90\% данных имели нормальное распределение, использованы методы параметрической статистики. Для оценки связей между бинарными признаками использован $\varphi$-коэффициент взаимной сопряженности (коэффициент ЧупроваКрамера). Критический уровень статистической значимости принят $<5 \%(\mathrm{p}<0,05)$.

Исследование выполнено в соответствии с принципами Хельсинской Декларации. Протокол исследования утвержден Локальным этическим комитетом указанного в работе учреждения. На проведение исследований получено информированное согласие врачей.

\section{Результаты исследования и их обсуждение}

Анализ результатов анонимного анкетирования показал, что 98\% (146) респондентов знают и используют в практической деятельности унифицированный протокол МЗ Украины № 499, владеют информацией по ведению пациентов с ОРВИ и гриппом. При этом только 20\% (30) врачей верно указали основные направления лечения согласно данному протоколу, хотя 100\% (149) опрошенных утверждали, что знают, какие группы препаратов нужно использовать при лечении гриппа и ОРВИ.

Современный подход в лечении ОРВИ базируется на использовании тех безопасных лекарственных средств с доказательной базой эффективности, которые в первую очередь характеризуются наличием действенного фармакологического контроля ведущих звеньев молекулярных механизмов развития острого инфекционного процесса на слизистых респираторного тракта, 
а именно, прямого противовирусного эффекта и, с другой стороны, обладают выраженными антиоксидантными свойствами. Сочетание данных свойств в препарате выбора для лечения ОРВИ, априори, способствует потенцированию двух эффектов - через прямой противовирусный компонент действия контролируется не только процесс дальнейшего развития инфекционного процесса на слизистых, но и усиливается антиоксидантная составляющая препарата, не связанная с инициацией иммунных механизмов усиления антиоксидантной защиты клетки, минимизируется непосредственное влияние самого вируса на продукцию активных кислородсодержащих метаболитов, что влияет на выраженность и течение инфекционного процесса и состояние здоровья ребенка [5,6,7]. Именно таким набором свойств обладают флавоноиды. Флавоноиды (от лат. flavus - желтый) - природные, фенольные соединения растительного происхождения, генетически связанные друг с другом и обладающие различными фармакологическими действиями.

В конце XX столетия были открыты противовирусные свойства флавоноидов. Сегодня доказано, что кверцетин сокращает общее количество дней болезни и уменьшает выраженность симптомов ОРВИ, обладает не только ингибирующим действием в отношении нейраминидазы гриппа, но и связывается с гемагглютинином, препятствует прикреплению вируса к клетке и проникновению в нее, а также гемолизу, опосредуемому гемагглютинином [2]. Последние исследования показали, что кверцетин оказывает прямое действие на аденовирус, РС-вирус, вирус парагриппа и позитивно влияет на развитие тяжелого острого респираторного синдрома (SARS), (14.02.2020 FDA - 503A Category 1) [4,8].

Для флавоноида ороксилин показано сочетание ингибирования нейраминидазы с индукцией интерферона, что также важно в опосредовании противовирусных эффектов (Jin J. Et al., 2017). Апигенин - сильный антиоксидант, обладает выраженным противовоспалительным эффектом, доказано его непосредственное влияние на энтеровирусы (Qian S.; Fan W.; Qian P.; et al., 2015; Fahad Ali, Rahul, Falaq Naz, Smita Jyoti, 2017). Лютеолин имеет антинейраминидазную активность, противовоспалительное и иммуномодулирующее действие [1,9].

На украинском фармацевтическом рынке сегодня особое внимание заслуживает линейка препаратов с действующим веществом проте- флазид. Биофлавоноиды, выделенные из биологически активного вещества (БАВ) протефлазид (БАВП), имеют химическую чистоту 93,8\% и относятся к флавонольным веществам, что подтверждает соответствие заявленным характеристикам - концентрация агликонов флавонола БАВП 0,48 мг/мл сопоставима c концентрацией флавоноидных гликозидов (0,32-0,45 мг/мл).

Противовирусное действие препаратов с действующим веществом протефлазид: доказательная база

Доказательная база противовирусной эффективности биофлавоноидов протефлазида отчеты Института эпидемиологии и инфекционных болезней НАМН Украины, находящиеся в открытом доступе:

- Проведение дополнительных клинических испытаний новых форм препарата Протефлазид (неофлазид, сироп протефлазида) (2003).

- Отчет о доклиническом изучении новых (лечебных) форм протефлазида на моделях вируса гриппа (2006).

- Изучение механизмов действия биологически активных веществ лечебной субстанции Протефлазид (2010).

- Анализ антивирусных свойств действующих веществ Протефлазида и экстраполяция действующих in vivo доз на человека (2011); данные отчета НИИ гриппа Экспериментальное изучение противовирусной эффективности препарата Протефлазид в отношении возбудителя гриппа A $(\mathrm{HlNl})$ на модели гриппозной пневмонии у животных (Санкт-Петербург, 2010).

По данным отчетов, биофлавоноиды Протефлазида ингибируют нейраминидазу вируса гриппа, активность обратной транскриптазы в бесклеточной системе, ДНК- и РНК-полимеразную и тимидинкиназную активность, при этом усиливают действие апоптоз-индуцирующих веществ. Изучение антинейраминидазной активности биофлавоноидов Протефлазида показало, что данный препарат в концентрации 4,8 мкг/мл полностью ингибирует нейраминидазную активность вируса гриппа А (H1N1) и стандартного препарата нейраминидазы Astrobacterureafacieus 105, что подтверждено также в опытах in vivo на модели гриппозной пневмонии у мышей и по эффективности сравнимо с осельтамивиром.

Из серии различных исследований по изучению антивирусной активности БАВП 
in vitro и in vivo сделаны следующие обобщающие выводы:

- полученный в исследованиях уровень химиотерапевтического индекса БАВП по отношению к вирусу гриппа, вирусам простого герпеса 1 и 2-го типов и некоторым другим вирусам свидетельствует о высокоселективном действии на репродукцию этих инфектов;

- БАВП, выделенный из Протефлазида, с присутствием углеводных структур, эффективно действует на вирусы гриппа, вирусы простого герпеса 1 и 2-го типов и некоторые другие вирусы.

В отношении ингибирования разных стадий репликативного цикла вирусов, что оценивалось при тестировании Протефлазида в трех ферментативных системах - транскрипции, репликации и релаксации, показало высокую активность биофлавоноидов действующего вещества протефлазид в отношении ингибирования синтеза ДНК-фрагментов вирусов и подтвердило наличие такого механизма антивирусного действия, как способность угнетать в инфицированных клетках РНК- и ДНК- полимеразы.

Антиоксидантные свойства действующего вещества протефлазид: доказательная база

Изучение влияния действующего вещества протефлазид на антиоксидантный статус клеток, проведенное с использованием экспериментально разработанной системы с постоянным генерированием активных форм кислорода с регистрацией и изучением влияния биофлавоноидов на интенсивность свободнорадикальных процессов, показало, что в присутствии протефлазида после двух часов инкубации клеток скорость генерации супероксид-радикал-аниона снижалась на $20-30 \%$, и более чем на $50 \%$ - после 4-часовой инкубации, а через 24 часа скорость генерирования этого радикала была близка к нулю. Также в образцах клеток, инкубированных с протефлазидом (хемилюминесцентный метод), развитие свободнорадикальных реакций носило замедленный характер.

Таким образом, подтверждено, что биофлавоноиды действующего вещества протефлазид проявляют доказанные антиоксидантные свойства, которые свидетельствуют о его способности повышать устойчивость клеток по отношению к свободнорадикальному стрессу.

Доказательная база клинической эффективности биофлавоноидов при лечении вирусных инфекций у иеловека

Проведенный коллективом авторов (Крамарев С.А., Гриневич А.И., Тонковид О.Б., Выгов- ская О.В.; 2014) метаанализ 30 клинических исследований эффективности флавоноидов при вирусных и вирусно-бактериальных заболеваниях у 2699 детей в первую очередь подтвердил безопасность применения и высокую эффективность флавоноидов (Протефлазид, Иммунофлазид, Флавозид) при лечении ОРВИ у детей за счет таких эффектов, как купирование лихорадки, уменьшение интоксикации, нормализации уровней лейкоцитов и лимфоцитов и снижению частоты рецидивов.

Системный анализ эффективности и безопасности применения Иммунофлазида в педиатрии (Бекетова Г.В., Хайтович Н.В., Гриневич А.И.; 2014), также подтвердил, что препарат у детей характеризуется высоким профилем безопасности при его долгосрочном ежедневном применении, а его компоненты - биофлавоноиды оказывают прямое противовирусное действие, повышают уровень неспецифической защиты, уменьшают развитие оксидативного стресса, уменьшают уровень провоспалительных цитокинов, стимулируют Т-хелперную активность и обладают иммуномодулирующими эффектами.

Cироп ФЛАВОВИР ${ }^{\circledR}$ - обновленный Иммунофлазид, действующее вещество - протефлазид, в составе которого комплекс биофлавоноидов (кверцетин, апигенин, лютеолин, трицин, рамназин) находится в матрице вспомогательных веществ - аминокислот, карбоновых кислот, сахаров и полимеров - полисахаров, пектинов, хлорофиллов ( $\mathrm{a}$ и b), гемицеллюлозы (А и В).

Применение ФЛАВОВИР ${ }^{\circledR}$ сироп при ОРВИ этиологически обосновано, так как на сегодня раскрыты полимишеневые механизмы молекулы протефлазид в серии до- и постклинических исследований. В частности, доказано ингибирование БАВП вирусоспецифических ферментов: ДНК-/РНК-полимераз, тимидинкиназы, обратной транскриптазы, нейраминидазы вируса гриппа, что подтверждает наличие у препарата ФЛАВОВИР ${ }^{\circledR}$ сироп прямого противовирусного действия как по отношению к РНК-содержащим вирусам, в том числе и гриппа, так и ДНК-содержащим вирусам.

Доказательная база эффективности и безопасности линейки лекарственных форм препаратов на основе действующего вещества протефлазид является уникальной - в период 2000-2017 гг. проведено более 230 клинических исследований (контролируемых сравнительных рандомизированных), в которых принимали участие более 22000 человек (табл. 1). 
Клиническое портфолио препаратов с действующим веществом протефлазид

\begin{tabular}{|l|c|c|c|c|c|}
\hline \multirow{2}{*}{ Нозология } & \multicolumn{5}{|c|}{ Клинические исследования по применению препарата } \\
& \begin{tabular}{c} 
с действующим веществом протедлазид \\
осщее \\
\cline { 2 - 6 } \\
\cline { 2 - 6 } \\
клинических \\
исследований
\end{tabular} & $\begin{array}{c}\text { общее } \\
\text { количество } \\
\text { пациентов в } \\
\text { исследованиях }\end{array}$ & $\begin{array}{c}\text { количество } \\
\text { пациентов, } \\
\text { принимавших } \\
\text { препарат }\end{array}$ & $\begin{array}{c}\text { количество } \\
\text { детей, } \\
\text { принимавших } \\
\text { препарат }\end{array}$ & $\begin{array}{c}\text { количество } \\
\text { беременных, } \\
\text { принимавших } \\
\text { препарат }\end{array}$ \\
\hline Грипп и ОРВИ & 21 & 2399 & 1719 & 1534 & 0 \\
\hline Герпесвирусная инфекция & 89 & 7438 & 4605 & 1532 & 545 \\
\hline Другие вирусные инфекции & 127 & 12445 & 5882 & 1057 & 829 \\
\hline Всего & 237 & 22282 & 12206 & 4123 & 1374 \\
\hline
\end{tabular}

Следует отметить, что по использованию БАВП у человека в Украине защищено 9 докторских и 38 кандидатских диссертационных работ, проведен ряд тематических метаанализов и систематических обзоров клинических наблюдений и отдаленных результатов применения препаратов, что опубликовано в научной литературе, а в помощь практическому здравоохранению разработаны 20 методических рекомендаций и 28 информационных писем «О нововведениях в системе охраны здоровья».

По данным анонимного анкетирования, на вопрос «Знают ли семейные врачи линейку препаратов с действующим активным веществом протефлазид, и если да, то как назначали?» получены следующие ответы. Для профилактики ОРВИ эти препараты в течение 1-2 недель рекомендовал каждый 3-4-й врач, а для лечения ОРВИ - каждый 2-й врач назначал от 4-5 дней до 2 недель. При ответе на вопрос «Можно ли препараты с активным действующим веществом протефлазид назначать беременным?» 121 (81\%) врач ответил положительно, 128 (86\%) врачей указали, что эти препараты можно назначать детям от рождения, 104(70\%) врача назначали эти препараты взрослым.

При анализе ответов семейных врачей на вопрос «За счет каких механизмов действия, по вашему мнению, препараты с действующим веществом протефлазид эффективны при ОРВИ?» получены следующие варианты ответов:

- оказывают прямое противовирусное действие;

- подавляют размножение вирусов;

- отсутствует токсическое действие (безопасные);

- обладают различными механизмами действия (полимишеневый препарат).

При этом анализ мнения родителей (обратная связь с врачом) показал следующие варианты ответов, характеризующих эффективность использования препаратов с действующим веществом протефлазид для лечения детей с ОРВИ:

- положительные отзывы;

- используют часто;

- сокращается период болезни;

- дети меньше болеют ОРВИ.

Также в этом блоке анкеты врачи амбулаторной практики ответили на вопрос «Какие клинические эффекты препаратов с действующим веществом протефлазид вы отмечали в собственной практике при лечении пациентов с ОРВИ?». Анализ ответов респондентов (рис.) относительно применения этих препаратов показал следующие результаты: 79 (53\%) врачей указали на сокращение продолжительности заболевания; 98 (66\%) - на уменьшение тяжести течения заболевания; 63 (42\%) на сокращение сроков и уменьшение интенсивности лихорадки; 84 (56\%) - на снижение проявлений интоксикационного синдрома; $82(55 \%)$ - на уменьшение частоты острых респираторных заболеваний (кратность в году).

Для установления достоверных связей между результатами анкетирования семейных врачей, при котором предполагались множественные ответы на один и тот же вопрос и разный выбор респондентов, проведена корреляция бинарных данных с учетом уровня коэффициента сопряженности, получен ряд достоверных результатов $(\mathrm{p}<0,05)$, представленных в таблице 2 .

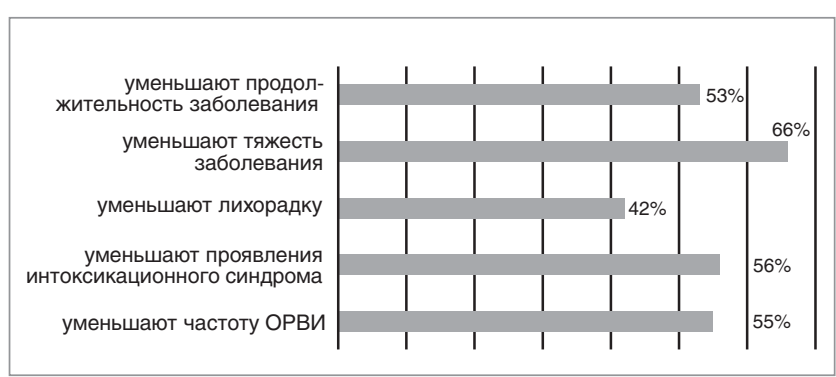

Pис. Удельный вес положительных ответов семейных врачей по регистрации клинических эфрфектов у пациентов, которых лечили препаратами на основе действующего вещества протефлазид 
Таблииа 2

Анализ $\varphi$-коэффициента сопряженности (связь между бинарными признаками; р<0,05) по результатам анкетирования

\begin{tabular}{|c|c|c|c|}
\hline \multicolumn{2}{|c|}{ Препарат/эффект применения } & Педиатр & $\begin{array}{l}\text { Семей- } \\
\text { ный врач }\end{array}$ \\
\hline \multirow[b]{2}{*}{ Протесрлазид } & лечение ОРВИ & $\varphi=0,43$ & $\varphi=0,51$ \\
\hline & $\begin{array}{c}\text { профрилактика } \\
\text { ОРВИ }\end{array}$ & $\varphi=0,41$ & \\
\hline \multirow[b]{2}{*}{ Иммунофрлазид } & лечение ОРВИ & & $\varphi=0,49$ \\
\hline & $\begin{array}{c}\text { уменьшение } \\
\text { тяжести ОРВИ }\end{array}$ & & \\
\hline \multirow{3}{*}{$\begin{array}{l}\text { Биофолавоноиды } \\
\text { (эфрфекты) }\end{array}$} & $\begin{array}{c}\text { уменьшение } \\
\text { тяжести ОРВИ }\end{array}$ & $\varphi=0,37$ & $\varphi=0,36$ \\
\hline & $\begin{array}{c}\text { сокращение } \\
\text { длительности } \\
\text { ОРВИ }\end{array}$ & & $\varphi=0,41$ \\
\hline & $\begin{array}{c}\text { уменьшение } \\
\text { кратности } \\
\text { ОРВИ }\end{array}$ & & $\varphi=0,48$ \\
\hline
\end{tabular}

По мнению семейных врачей, препараты c действующим веществом протефлазид для лечения и профилактики ОРВИ безопасные (отсутствует токсическое действие) и эффективные (по собственным наблюдениям), за счет уменьшения продолжительности и тяжести заболевания, выраженности лихорадки и проявлений интоксикационного синдрома, снижения частоты острых респираторных заболеваний (кратность за год). Вышеописанные эффекты в практике опрошенных семейных врачей связаны с прямым противовирусным действием, подавлением размножения вирусов и множественными механизмами действия биофлавоноидов протефлазида, кото- рые подтверждены обширной базой доклинических исследований.

Помимо профессионального мнения семейных врачей, достаточно важным является мнение родителей об эффективности препаратов с действующим веществом протефлазид для лечения и профилактики ОРВИ (обратная связь с врачом). Получены положительные отзывы и сделаны отметки о том, что родители часто используют эти препараты при самолечении, а такой выбор связан с тем, что препараты линейки протефлазида сокращают период болезни и, по отзывам родителей, дети меньше болеют ОРВИ.

\section{Выводы}

Доказанное в современной мировой практике противовирусное действие флавоноидов как класса полифенольных соединений, а также доказанный механизм противовирусной активности флавоноидов, входящих в состав препарата Флавовир, что в клинической амбулаторной практике подтверждено положительным опытом врачей первичного звена (выраженная клиническая эффективность), позволяет рекомендовать Флавовир сироп для лечения и профилактики гриппа и сезонных ОРВИ детям от рождения.

Материал подготовлен при содействии компании ООО «НПК «Экофарм».

Авторы заявляют об отсутствии конфликта интересов.

\section{REFERENCES/ЛITEPATУPA}

1. Aziz N, Kim MY, Cho JY. (2018). Anti-inflammatory effects of luteolin: A review of in vitro, in vivo, and in silico studies. Journal of ethnopharmacology. 225: 342-358. URL: https://doi.org/ 10.1016/ j.jep.2018.05.019

2. Batiha GE, Beshbishy AM, Ikram M, Mulla ZS, El-Hack M, Taha AE, Algammal AM, Elewa Y. (2020). The Pharmacological Activity, Biochemical Properties, and Pharmacokinetics of the Major Natural Polyphenolic Flavonoid: Quercetin. Foods (Basel, Switzerland). 9 (3): 374. URL: https://doi.org/10.3390/foods9030374.

3. Kuznetsova L. (2017). Influence of flavonoids on the cellular immunity indices in children and adolescents with influenza and acute respiratory viral infections before and after treatment. «Laboratory diagnostics. Eastern Europe». 6 (3).

4. Li Y, Yao J, Han C, Yang J, Chaudhry MT, Wang S, Liu H, Yin Y. (2016). Quercetin, Inflammation and Immunity. Nutrients. 8 (3): 167. URL: https://doi.org/10.3390/nu8030167.
5. Mondal S, Rahaman ST. (2020). Flavonoids: A vital resource in healthcare and medicine. Pharm Pharmacol Int J. 8 (2): 91-104.

6. Mukvich OM, Kaminskaya TM. (2017). Preventive and therapeutic effectiveness of bioflavonoids in children with recurrent respiratory infections. CHILDS HEALTH. 12 (2): 124-129.

7. Wang L, Song J, Liu A, Xiao B, Li S, Wen Z, Lu Y, Du G. (2020). Research Progress of the Antiviral Bioactivities of Natural Flavonoids. Natural products and bioprospecting. 10 (5): 271-283. URL: https://doi.org/10.1007/s13659-020-00257-x.

8. Wu W, Li R, Li X, He J, Jiang S, Liu S, Yang J. (2015). Quercetin as an Antiviral Agent Inhibits Influenza A Virus (IAV) Entry. Viruses. 8 (1): 6. URL: https://doi.org/10.3390/v8010006.

9. Yan H, Ma L, Wang H, Wu S, Huang H, Gu Z, Jiang J, LiY. (2019). Luteolin decreases the yield of influenza $A$ virus in vitro by interfering with the coat protein I complex expression. Journal of natural medicines. 73 (3): 487496. URL: https://doi.org/10.1007/s11418-019-01287-7.

Відомості про авторів:

Височина Ірина Леонідівна - д.мед.н., проф., зав. каф. сімейної медицины факультету післядипломної освіти ДУ «Дніпропетровська медична академія МОЗ України Адреса: м. Дніпро, вул. Бардіна, 1. https://orcid.org/0000-0003-3532-5035.

Крамарчук Володимир Вікторович - асистент каф. сімейної медицины факультету післядипломної освіти ДУ «Дніпропетровська медична академія МОЗ України».

Адреса: м. Дніпро, вул. Бардіна, 1. https://orcid.org/0000-0002-4224-6493.

Стаття надійшла до редакції 28.07.2020 р., прийнята до друку 06.10.2020 р. 


\section{Ф^авовір \\ ПРОТИВІРУСНИЙ ЗАСІБ}

avereside

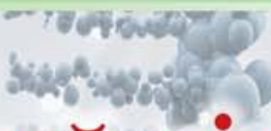

Науковий пі ххі $\Delta о$ мікування і профрікактики ГРВІ та грипу

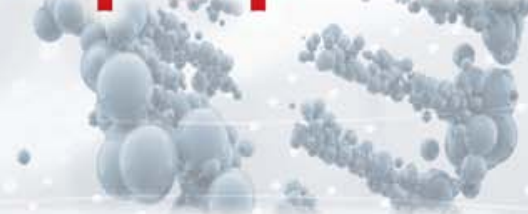

ПРЯМА ПРОТИВІРУСНА ДІЯ ПРОТИ ВІРУСІВ ГРВІ ТА ГРИПУ

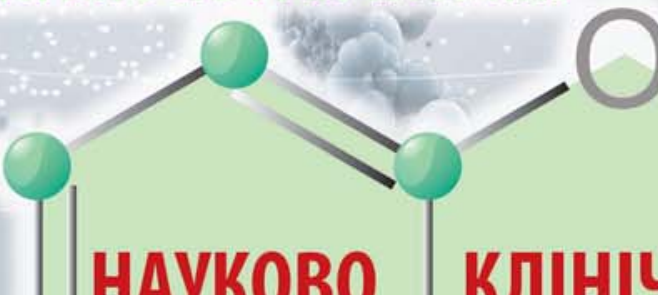

НАУКОВО

ОПИСАНИИ МЕХАНІЗM
КЛІІІІНО

ППДТВЕРДЖЕНА ЕФЕКТИВНІСЬ
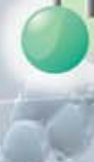

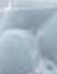

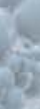

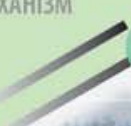
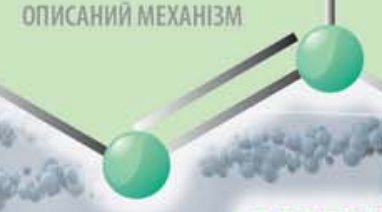

З ЗМЕНШУЕ

- .

\section{सูखस २े ПОЛЕГШУЄ \\ ПЕРЕБ|Г ${ }^{1}$}

Інструкція для медичного застосування лікарського засобу, сиропу ФЛАВОВІР* (витяг)

Реєстраційне посвідчення на лікарський засіб №UA5510/01/01 (наказ МО3 від 15.09.2016 року №973 зі змінами), дійсне до 15.09 .2021 року)

Склад: 1 мл сиропу містить: 0,02 мл рідкого екстракту Протефлазід, отриманого із суміші трав (1:1) Щучки дернистої (Herba Deschampsia caespitosa L.) та Війника наземного (Herba Calamagrostis epigeios L.) (розчинник екстракції - етанол 96\%), що еквівалентно не менше 0,0035 мг флавоноїдів у перерахунку на рутин; допоміжні речовини: пропіленгліколь, етанол 96\%, сорбіт (E 420), метилпарабен (E 218), пропілпарабен (E 216), натрію сульфіт (E 221), вода очищена. Код ATX J05A X. Код ATX L03A X. Спосі6 застосування та дози. Сироп слід дозувати за допомогою дозуючої ємності та приймати перорально за 20-30 хвилин до їди. Дози та тривалість лікування залежать від характеру захворювання та віку пацієнта. Для лікування грипу та ГPВI (при неускладненому перебігу захворювання) сироп застосовувати протягом 5 днів. Для профілактики грипу та ГРВІ сироп застосовувати протягом від 1 до 4 тижнів в дозі, яка складає половину лікувальної дози. У разі виникнення бактеріальних ускладнень грипу та інших ГРВІ з метою нормалізації показників імунної системи сироп можна застосовувати протягом 4 тижнів і довше. Діти. Флавовір застосовувати дітям від народження. Показання. Етіотропне лікування та профілактика ГРВІ; етіотропне лікування та профілактика грипу, у тому народження. Показання. Етіотропне лікування та профілактика ГРВІ; етіотропне лікування та профілактика грипу, у тому числі спричиненому вірусами пандемічних штамів. Протипоказання. Підвищена чутливість до компонентів препарату. Виразкова хвороба шлунка або дванадцятипалої кишки у стадії загострення. Аутоімунні захворювання. Побічні реакції. Алергічні реакції: в осіб із підвищеною чутливістю можуть мати місце реакції гіперчутливості. Можуть виникати алергічні випадки шлунково-кишкових розладів - біль в епігастральній ділянці, нудота, блювання, діарея (при наявності даних симптомів необхідно приймати сироп через $1,5-2$ години після іди). У пацієнтів з хронічним гастродуоденітом можливе загострення гастродуоденіту, виникнення гастроезофагеального рефлюксу (рефлюкс-езофагіту). Загальні розлади: можливе транзиторне підвищення температури тіла до $38^{\circ} \mathrm{C}$ на 3-10-и день терапії препаратом, головний біль. У разі виникнення будь-яких небажаних реакцій необхідно звертатися за консультацією до лікаря.

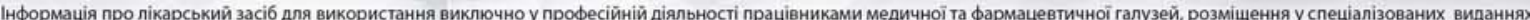

а також роз (наказ МОЗ від 15.09.2016 року №73 зі змінами), дійсне до 15.09.2021 року.

ТОВ «Науково-виробнича компанія "Екофарм»

04210, Україна, м. Київ, вул. Оболонська набережна, буд. 19, корпус 1

Тел/факс: (044) 594-05-96

office@ecopharm.ua www.ecopharm.ua
Заявник (виробник). ТОВ «НВК «Екофарм»

Адреса виробничих потужностей.

украіна, 30070 Хмельницька обл, с. Упашанівка, вул. Шевченка, 116.

flavovir.com.ua

\section{3 ПЕРШОГО ДНЯ ЖИТТЯ}

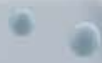

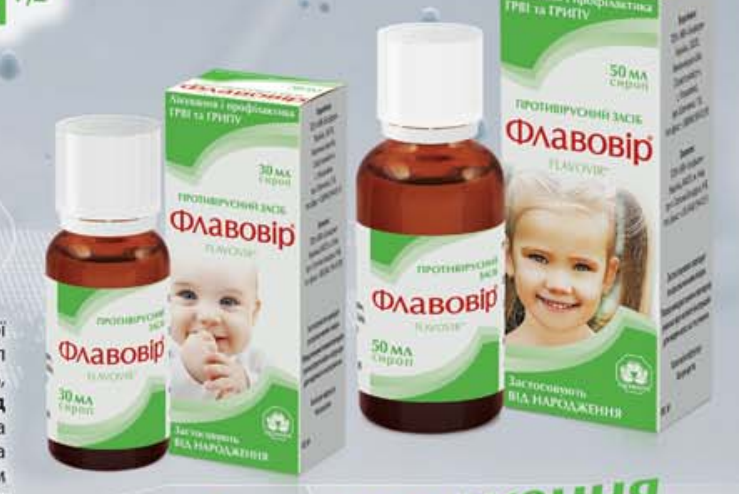

BiА наромженНЯ

1. Рыбалко СЛ. Изучение механизмов действия биологически активных веществ лечебной субстанции Протефлазида, 2010 2. 2. Знаменская Т.К Воробьева О.В. Современные аспекты профилактики и лечения гриппе ОРВИ у детей // Современная педиатрия 6(86)/2017. 3. Токарчук Н.І. Використання Імунофлазіду для профілактики та лікування грипу і ГPB у дітей під час сезонного підвищення захворюваності/ Н.І. Токарчук, Л.С. Саринець // Современная педиатрия 1/2012.

\section{ЛИШЕ ДВІЧІ НА ДОБУ}

